\title{
Research on Accounting Talent Cultivation Model Based on Modern Apprenticeship_-Taking Hainan Vocational and Technical College as an Example
}

\author{
Chunchao Liu, Yinzhen Huang, Linna Li \\ Hainan College of Vocation \& Technique, Haikou, Hainan 570216, China
}

\begin{abstract}
Keywords: modern apprenticeship, accounting talent, training mode.
\end{abstract}
\begin{abstract}
At present, there is a big gap between the training quality of the accounting profession and the market demand in China's higher vocational colleges. The modern apprenticeship system is a new talent cultivation model that adapts to the requirements of economic development and industrial structure adjustment. The article takes modern apprenticeship as the research object, taking Hainan Vocational and Technical College accounting as an example. Based on the current situation of school-industry cooperation, it analyzes the implementation conditions of government policy orientation, Hainan economic development characteristics, and school resources and experience. Construct the implementation line of the modern apprenticeship system for accounting majors, and initially form a talent training model for modern apprenticeship in the accounting profession.
\end{abstract}

\section{Introduction}

As we all know, higher education serves socio-economic development. At present, China's economic development is undergoing a transformation and the industrial structure is undergoing adjustment. However, in China's higher vocational education, school-enterprise cooperation and a combination of work-study talent training model have caused many problems in the actual development process. For example, the enthusiasm of enterprises to participate in school-enterprise cooperation is not high, the level of cooperation is not the same, the degree of participation is not deep, the operating mechanism of school-enterprise cooperation is not smooth, the cooperation agreement is not standardized, and the effect of education is not obvious. This shows that the current training model has been difficult to adapt to the needs of economic development of skilled personnel. To this end, the "modern apprenticeship" came into being. It is essentially a modern vocational education system. It is a close combination of school diploma education and corporate job training. It is a close integration of enterprise work-based training and school-based education. It is a deep integration of production and teaching.

\section{The main features and problems of the "modern apprenticeship system" of the accounting personnel training model in higher vocational colleges}

First, the school-enterprise dual-sports sports people must have a cooperative enterprise. The accounting profession is different from other occupations. Every enterprise and institution needs few people and is relatively fixed, and the accounting profession also involves the business of each enterprise. Confidential, so finding the right partner company is difficult.

Second, the joint enrollment of schools and enterprises means that "recruitment means recruitment, recruitment means recruitment, and graduation means employment". From the perspective of the enterprise, the purpose of recruiting companies is to require employees to create value for the company. We have seen a lot of recruitment information for accounting personnel. There is almost one such thing: "2-3 years of work experience" and so on. Companies are reluctant to spend time, financial resources and manpower to build a finance professional from scratch, and they will not leave their jobs waiting for the apprentice.

Third, apprentices have a dual identity (corporate employees, school students). Since it is a company employee, it must have a "employment contract". In accordance with the provisions of the 
"labor law", enterprises must buy "five risks and one housing fund" for them. At this time, the "apprentice" has not officially entered the post yet. There are too many uncertainties in apprenticeships from the period of "recruitment (recruitment)" to "graduation (employment)", which makes it difficult to realize the dual status of apprentices.

Fourth, school-enterprise joint training, work-study alternately, with "teacher and disciples" job training, job talent. The so-called "co-cultivation" is the enterprise master and school teachers to jointly study, develop courses, theoretical knowledge taught by the school teachers, job skills from the company's master "in the post" training, the implementation of "study and engineering alternate", the job talent. As we all know, each position of the company has its own job responsibilities, and it has its own business to do. The company will not raise "leisure people". The energy of the company's master is limited. Even if the apprentice reaches the work position, it is only "miscellaneous", "the real thing" practice doesn't make "the apprentice" to do, and the master is also afraid of problems and takes responsibility.

\section{An analysis of the implementation environment of the modern apprenticeship system for accounting personnel training in higher vocational colleges}

In order to ensure the smooth implementation of the "modern apprenticeship" talent training model, at least the following three basic conditions should be met.

(1) The government's policy support is supported by relevant laws.

As early as in 2014, the Ministry of Education issued the "Opinions on the Pilot Work of Modern Apprenticeship" and it pointed out that it is necessary to fully understand the significance of the pilot work, clarify the general requirements of the pilot work, grasp the connotation of the pilot work, steadily advance the pilot work, and improve the work guarantee mechanism in five parts. n order to implement this opinion, we will further promote the close integration of vocational education and industrial enterprises, improve the school-enterprise cooperation and educating mechanism, and innovate the model of technical and skilled personnel training. Hainan Provincial Department of Education organized research on the status of modern apprenticeships in vocational schools. We will provide the basis for the introduction of relevant documents for modern apprenticeship pilots with local characteristics in Hainanese enterprises and industries, and effectively promote the pilot work. Hainan Vocational and Technical College is one of the first universities in China to be selected as a pilot for modern apprenticeships. It is also the only pilot institution for modern apprenticeships registered in the Ministry of Education of Hainan Province.

At the end of 2017, the State Council issued a "Several Opinions on Deepening the Integration of Production and Education". The document includes 30 policies in 7 areas. This is a concrete measure for the deepening of integration of production and education by the National Development and Reform Commission and the Ministry of Education. Recently, six departments such as the Ministry of Education jointly issued the "Professional School-Enterprise Cooperative Promotion Measure" (Faculty-Enterprise Cooperation Promotion Program), Faculty of Education, [2018] No. 1, which aims to clarify the objectives, main bodies, forms of cooperation, and promotion measures for school-enterprise cooperation in vocational schools. Supervision and inspection, etc., establish a basic institutional framework for school-enterprise cooperation, which is of great significance in deepening the integration of production and education, school-enterprise cooperation, and struggling to manage vocational education in the new era. The "Opinions" focuses more on the integration of production and education. The "Measures" focus more on school-enterprise cooperation. The two documents together form the policy of implementing the Party's Nineteenth Congress in the field of vocational education, and the policy of integrating production and education and school-enterprise cooperation into in-depth policy "combination boxing", this is the biggest good news for the "modern apprenticeship" pilot.

(2) The characteristics of regional economic development are suitable for modern apprenticeship personnel training, and there are cooperative enterprises and institutions for protection. 
As we all know, Hainan builds "international tourism islands" mainly based on tourism and real estate. There are basically no large-scale industrial and mining enterprises. There are many small and medium-sized enterprises that deal with services such as tourism, consulting, and trade, and agricultural products, seafood, and small arts and crafts. Since the opening of the province for 30 years, small and medium-sized enterprises in Hainan Province have experienced rapid development, especially the construction of new rural areas and the rise of rural tourism. These enterprises all require accounting and tax returns. Some of the larger companies have their own accounting departments; some small and medium-sized enterprises that do not have much economic business have outsourced bookkeeping and tax reporting, resulting in an exponential increase in accounting firms and bookkeeping companies, and they have also established "accounting for books". Associations like this provide corporate protection for the professional implementation of modern apprenticeships in finance and accounting.

(3) The school has the resources and experience of school-enterprise cooperation.

The number of university-enterprise cooperation enterprises and the strength of school-enterprise cooperation are important resources and experiences for schools in implementing modern apprenticeships. Hainan Vocational and Technical College is a mixed ownership institution of higher vocational education. Its major shareholder is "Luo Niu Shan Group Corporation". This deepens the cooperation between schools and enterprises, and schools and enterprises are more flexible in cooperation in running schools. At present, the school has nearly 100 school-enterprise cooperation units and off-campus training bases, and has achieved a combination of on-campus and off-campus personnel training models. In order to strengthen the cooperation with enterprises, our school cooperates with many enterprise units such as Hainan Rural Credit Cooperatives to set up ordering classes and train talents.

\section{4. "Modern Apprenticeship" Higher Vocational Accounting Talent Training Model Implementation}

(1) Under the promotion of the government, find suitable cooperative enterprises and units.

At the time of filing and filing, Hainan Vocational and Technical College's pilot project for modern apprenticeship in the accounting profession cooperated with Luo Niu Shan Group. At that time, Luo Niu Shan Group was considered to be a major shareholder of the university. It should be convenient in terms of communication and coordination, but it was not actually the case. Due to the special nature of the accounting profession, although Luo Niu Shan Group has hundreds of subsidiary companies and nearly 300 accounting positions, these posts are distributed in the entire province of Hainan and cannot draw up specialized personnel to establish professional departments to coordinate After all, this is not their main business, so it failed to achieve the purpose of deep cooperation. Later, we added the "Accounting Association of Hainan Province" as the cooperating unit. There are nearly a hundred financial consulting companies and bookkeeping companies in the Association, which contracted the accounting and taxation services of various small and medium-sized enterprises in Hainan Province. Due to the large number of businesses these companies undertake, accounting chiefs are in urgent need of accounting personnel to join us. Our students (apprentices) also need to be directly "actualized" under the guidance of accounting chiefs (masters) and accept financial industry training in different industries. Professionals do professional things. The Hainan Provincial Institute of Accounts and Accounts is actually the agency responsible for coordination and communication.

(2) School-enterprise joint recruitment (recruitment) to clarify the dual status of students and apprentices.

Due to the special nature of the accounting profession, it is almost impossible to completely implement the "recruitment is the recruitment of workers" or "recruitment is the recruitment of students". Therefore, the Hainan Vocational and Technical College’s modern apprenticeship program for accounting majors adopts the "recruitment and recruitment" method, which enrolls students first by enrolling students in the school. On the one hand, students can learn accounting knowledge through professional courses, and on the other hand, through various finances. Consulting 
opportunities for consulting companies and bookkeeping companies Learn about accounting professions. In the fourth semester, according to the principle of two-way selection, apprentices, schools, and companies signed a tripartite agreement to clarify the rights and interests of all parties and become employees of the company. The enterprise provides corresponding training for students who have obtained dual status, and organizes students to alternately develop apprenticeships in schools and enterprises. Students apply the learned knowledge to work in the corresponding positions in the enterprise, combining the top job with employment.

(3) School-enterprise co-cultivation, work-study alternately, training with "master with apprenticeship", and job development

Modern apprenticeship highlights the "dual main sportsman." First of all, schools and enterprises need to determine the general goal of "modern apprenticeship" training based on the "accounting post occupational skills" as the core, and the modern enterprise's demand for accountants. At the same time, analyze the characteristics of small and medium-sized enterprises in Hainan, and combine the education supply in China. The "Reform" policy has established the implementation line of the modern apprenticeship system for accounting majors, refined the training objectives, and met the "precision supply" of the needs of the accounting personnel of the industry enterprises. Second, the schools and enterprises jointly established post standards, curriculum standards and assessment standards, and jointly developed Courses, build curriculum systems, jointly develop personnel training programs, and at the same time improve modern apprenticeship personnel training programs in the course of continuous practice.

(4) The teaching arrangement of the "modern apprenticeship" talent training mode in the accounting profession.

Schools and enterprises are co-constructing the mode of modernization of apprenticeships in modern engineering apprenticeships. Hainan Vocational and Technical College adopts the "phased apprenticeship, centralized practice, and sub-adult education" approach. The specific teaching arrangements are as follows:

In the first semester, students mainly completed the study of general education courses prescribed by the government. They mainly learned the knowledge and skills of two basic professional courses: "Basic Accounting" and "SME Cashier Practice", the basic courses of the specialty used the "integration of tangible and practical materials" to carry out project-based assessments, including professional basic knowledge. It is taught and assessed by the teachers in the school. Professional basic skills are taught and assessed by the company's master. The students are mainly in school but the internship time is not less than 4 weeks.

In the second semester, students' study is mainly specialized basic courses and professional core courses. The professional basic courses "Financial Regulations" and "Primary Accounting Computerization" is to be completed in the current semester; the other two core professional courses "Corporate Financial Accounting" and "Financial Software Applications" are part of this semester. The course adopts "integrated and rationalized" teaching materials and implements project-based assessment. Professional knowledge is taught and assessed by school teachers. Professional skills are taught and assessed by the company's master, students' study time at the university and internships in the company account for $50 \%$ of the time. After the end of the semester, students should have basic accounting knowledge and skills, be able to take the exam for accounting qualification, and obtain a certificate.

In the third semester, students must complete the study of professional core courses, have a more comprehensive grasp of professional core knowledge and professional core skills, and have a certain professional comprehensive ability. The core professional courses offered during the semester include: "Corporate Financial Accounting", "Financial Software Applications", "Enterprise Costing" and "Corporate Taxation Practices and Online Tax Filing". All the courses adopt the "integrated reality" teaching materials and carry out project-based assessments. Among them, professional knowledge is taught and assessed by teachers in the school. Professional skills are taught and assessed by the company's masters. Students take up $50 \%$ of the time in school and internships in business. 
In the fourth semester, students already have relatively comprehensive accounting professional knowledge and master certain post occupational skills. They are already "apprentice apprentices". They are arranged to work in companies for rotation practice. In the first 8 weeks, students are not internships in accounting positions, but in companies. The internships in other departments and positions can also be called professional experience because, in terms of the characteristics of accounting profession, accounting personnel can only correctly and objectively make professional judgments when they are familiar with the business of various departments and positions of the company. Doing a good job in accounting; after 10 weeks of time, students perform rotation practice in accounting positions. The assessment of this stage is entirely at the discretion of the company's master.

In the fifth semester, after the rotation practice in the fourth semester, the students were positioned according to their personality traits and acquired professional knowledge. After returning to school, the students followed their intended career positions. The selection of professional development courses (optional) for learning, optional courses are: "audit practice", "Excel in financial applications", "industry accounting comparison", "financial management and accounting statement analysis", "before and after the cashier Skills Training, Pre-job Skill Training for Materials and Materials, Pre-practice Skills Training for Sales Accounting, Pre-employment Skills Training for Employees' Compensation, Pre-practice Skills Training for Settlements, and Pre-job Skill Training for Pre-asset Accounting The first four courses are mainly taught in schools, taught and assessed by school teachers, and the latter six courses are mainly used for internships in corporate accounting positions. The company's masters impart professional skills and assessments. This kind of teaching arrangement is to achieve "accurate training and accurate supply".

In the sixth semester, students take the position of "quasi-employee" to the company to perform postgraduate internships. They are fully evaluated by the company's masters, qualified for assessment, and converted to formal employees to achieve apprenticeship and employment.

\section{Acknowledgements}

Fund Project: This is the phased achievement of Hainan Vocational and Technical College's 2016 school-level general project "Study on Accounting Professional Training Model Based on Modern Apprenticeship” project number HZY2016-7;

This article is the phased achievement of Hainan Province Education and Teaching Reform Research Project "Hainan Province Vocational Education Modern Apprenticeship Practice Research” project number Hnjg2016ZD-23.

\section{References}

[1] Xie Nina. "Modern Apprenticeship" Talent Training Model [J]. Cooperative Economy and Technology, 2016(4): 136-138.

[2] Miao Qijun. Research on accounting modern apprenticeship under the bookkeeping simulation teaching model [J]. Business Accounting, 2015(7): 105-108.

[3] Tian Ke. Study on Modern Apprenticeship of Accounting Major in Higher Vocational Colleges of Maritime [J]. Section, 2015(9): 63.

[4] Wang Ling. Technical regulations for developing Dual Certificate Curriculum in school enterprise cooperation under modern apprenticeship system [J]. Vocational Education Forum, 2014, (21): 66-69.

[5] Xie Junhua. Discussion on the Mode of Modern Apprentice Talent Cultivation in Higher Vocational Colleges [J]. Vocational Education Forum, 2013, (16): 24-26. 